\title{
GEOCHEMISTRY OF OPHIOLITE COMPLEX IN NORTH KONAWE, SOUTHEAST SULAWESI
}

\section{GEOKIMIA KOMPLEK OPHIOLIT DI KONAWE UTARA, SULAWESI TENGGARA}

\author{
Ronaldo Irzon* dan Baharuddin \\ Pusat Survei Geologi - Kementerian ESDM, \\ JL. Diponegoro 57, Bandung, Jawa Barat 40122 \\ *E-mail: ronaldo_irzon@yahoo.com
}

Naskah diterima: 28 Juni 2016, direvisi: 2 Agustus 2016, disetujui: 21 November 2016

\begin{abstract}
Southeast Sulawesi is crosscutted by Lasolo Fault into two geological provinces: Tinondo and Hialu. Tinondo Geological Province is occupied largely by Ophiolite Complex in the northern part of Southeast Arm of Sulawesi. No study was conducted in relation to the geochemistry composition of Ophiolite Complex in North Konawe Regency. The aim of this study is to describe the ultramafic rock of the Ophiolite Complex in North Konawe Regency using field, geochemical, and petrographical analysis. Megascopically, the selected nine samples are described as greyish to blackish and fine to medium grains ultramafic rocks, which consist of pyroxene and olivine. Microscope, X-Ray Fluorescence (XRF), and Inductively Coupled Plasma Mass Spectrometry (ICP-MS) devices were used to obtain both petrography and geochemistry data. Major oxides data confirm that the selected samples are classified into ultramafic rocks as $\mathrm{SiO}_{2}, \mathrm{MgO}$, and $\mathrm{Fe}_{2} \mathrm{O}_{3 \mathrm{~T}}$ are the most abundant oxides. The studied samples presumably came from arc tholeiitic environment tectonic setting. Ultramafic rocks often contain promising economic metals whereas the average numbers of $\mathrm{Ni}, \mathrm{Mn}, \mathrm{Cr}$, and $\mathrm{Co}$ of this study are 2,675;1,074; 2,386; and 117 ppm respectively. The rocks are generally enriched in high field strength elements whilst rare earth elements value are low, ranging from 2.11 to 7.10 ppm. Microscopically, samples can be classified into three groups: olivine-hornblende pyroxenite, lherzolite, and olivine websterite. Geochemical data describes more about the discriminant analysis of the groups.
\end{abstract}

Keywords: North Konawe, ophiolite, ultramafic, geochemistry

\begin{abstract}
ABSTRAK
Wilayah Sulawesi Tenggara dipotong oleh Sesar Lasolo yang membagi daerah ini menjadi dua lajur: Tinondo dan Hialu. Lajur Tinondo diisi sebagian besar oleh Komplek Ophiolit, yang berada di bagian utara dari Lengan Tenggara Sulawesi. Belum ada studi yang terfokus kepada kandungan geokimia Komplek Ophiolit tersebut di wilayah Kabupaten Konawe Utara.Studi ini bertujuan untuk mempelajari karakter batuan ultramafik dari Komplek Ophiolit di Kabupaten Konawe Utara melalui kegiatan lapangan, analisis geokimia, dan analisis petrografi. Secara megaskopis, sembilan contoh batuan terpilih teridentifikasi sebagai batuan ultramafik berwarna kelabu hingga hitam, berukuran butir sedang hingga halus, dan mengandung piroksen maupun olivine. Perangkat mikroskop, X-Ray Fluorescence (XRF), dan Inductively Coupled Plasma Mass Spectrometry (ICP-MS) dimanfaatkan untuk memperoleh data geokimia maupun mikroskopis. Data oksida utama mengklasifikasikan contoh terpilih ke dalam batuan utramafik dengan $\mathrm{SiO}_{2}, \mathrm{MgO}$, dan $\mathrm{Fe}_{2} \mathrm{O}_{3 \mathrm{~T}}$ sebagai oksida dengan kelimpahan tertinggi. Contoh terpilih mungkin terbentuk pada lingkungan busur tektonik tholeitik. Batuan ultramafik sering mengandung logam ekonomis dengan kadar rata-rata Ni, Mn, Cr, dan Co pada studi ini adalah: 2.675, 1.074, 2.386, dan 117 ppm secara berurutan. Batuan telah mengalami pengayaan unsur high field strength elements meskipun dengan kadar unsur tanah jarang yang rendah, berkisar dari 2,11 hingga 7,10 ppm. Secara petrografi, batuan terpilih dapat dibagi menjadi tiga kelompok: olivine-hornblende pyroxenite, lherzolite, and olivine websterite. Data geokimia menjelaskan lebih lanjut mengenai perbedaan dari kelompok-kelompok tersebut.
\end{abstract}

Kata kunci: Konawe Utara, ofiolit, ultramafik, geokimia 


\section{INTRODUCTION}

Ophiolite complex is mostly occupied by ultramafic rocks, a division of igneous rock with generally high $\mathrm{MgO}$ (more than $18 \%$ ) and $\mathrm{FeO}$ content, but very low silica $(<45 \%)$ and potassium. This group composed the Earth's Mantle and is built of more than $90 \%$ dark, high $\mathrm{Mg}$ and Fe (mafic) minerals. The majorities of ultramafic rocks are exposed in orogenicbelts, predominate in Archaean and Proterozoic terranes, and may contain useful information on the tectonic regimes in which the early continental crust was assembled. This is because lithologies of the ophiolitic suite which are considered diagnostic of subduction tectonic settings in Phanerozoic orogens [1]. Chromium, Nickel, Cobalt, Manganese and other associated metals are the valuable geological resources related to ultamafic rocks [2 - 4]. Ni laterite that produced by prolonged and deep weathering of $\mathrm{Ni}$ silicate-bearing ultramafic rocks has become an important resources of $\mathrm{Ni}$ and ferronickel with around $40 \%$ of world annual $\mathrm{Ni}$ production [5]. Moreover, the platinum group elements (PGE: Ru, Rh, Pd, Os, Ir, Pt) tend to be correlated with ultramafic complex and has become interesting topic because of economical value of PGE $[6,7]$.

The biggest ophiolite outcrop in Sulawesi is located on Southeastern Arm; even smaller ophiolite complex occurrences also described in the South Arm [8]. Ultramafic rocks, the important sequence of ophiolite, distributed in many locations in eastern Indonesia which also being explored and exploited for national interest. North Konawe (Konawe Utara) is regency in Southeast Sulawesi Province where some of the area is comprised of Early Cretaceous Ophiolite Complex. The regency is part of Kawasan Strategis Nasional Soroako (Sorowako National Strategic Area) because of the nickel commodity. Some studies related to $\mathrm{Ni}$ resources of ultramafic complex, including the weathered layers, conducted in South Konawe [9, 10]. Some companies, PT Kembar Mas Sutra, PT Elit Karisma Modern, PT Konutara Sejati, PT Karya Tama Konawe Utara, and PT Cinta Jaya, are five nickel mining companies which committed to build nickel smelter in the regency.

This study is focussing on the ultramafic rock unit from North Konawe regency in Zalm quadrangle. The aim of the study is to characterize the ultramafic complex by using field, geochemical, and petrographical studies. Eventhough several researches were focussing the primary mineral resources $(\mathrm{Ni}$, $\mathrm{Co}, \mathrm{Mg}$ ) in the regency, none of them displaying major, trace, and rare earth elements composition of the ultramafic rock. Moreover, two subgroups of ultramafic complex were mapped using geochemistry data and microscopic results.

\section{Regional Geology}

Southeast Sulawesi is crosscutted by a number of large faults striking NW-SE: Lasolo, Matano, Kolono, and Kolaka faults [11]. The study area distinguished into two geological provinces, which separated by Lasolo Fault. Tinondo Geological Province characterized by continental shelf deposits where Hialu is an exhibited oceanic crust deposits [12]. Meluhu Formation and Tokala Formation are the two oldest metasedimentary rock units distributed in the southern part of Lasusua-Kendari Quadrangle. Both of the Triassic rock formations were included into Hialu Geological Province. This study is focusing on the Tinondo Geological Province, which occupied by Ophiolite complex in North 
Konawe Regency (Figure 1). The studied ophiolite complex is considered to emplaced in Early Cretaceous. The ultramafic group composition is ranging from peridotite, harzburgite, dunite, gabbro, and serpentinite [13]. Late Cretaceous Matano Formation unconformably overlain the ultramafic rocks, and composed of calcilutite with shale and chert intercalations. Oligocene Salodik Formation comprises of calcilutite and oolitic limestone, distributed in Tampakura Mountains, northeastern of the quadrangles. The Salodik Formation classified into Coral Limestone [14]. Conglomerate, sandstone and claystone were composing Pandua Formation as a part of Sulawesi Molasse Deposits.

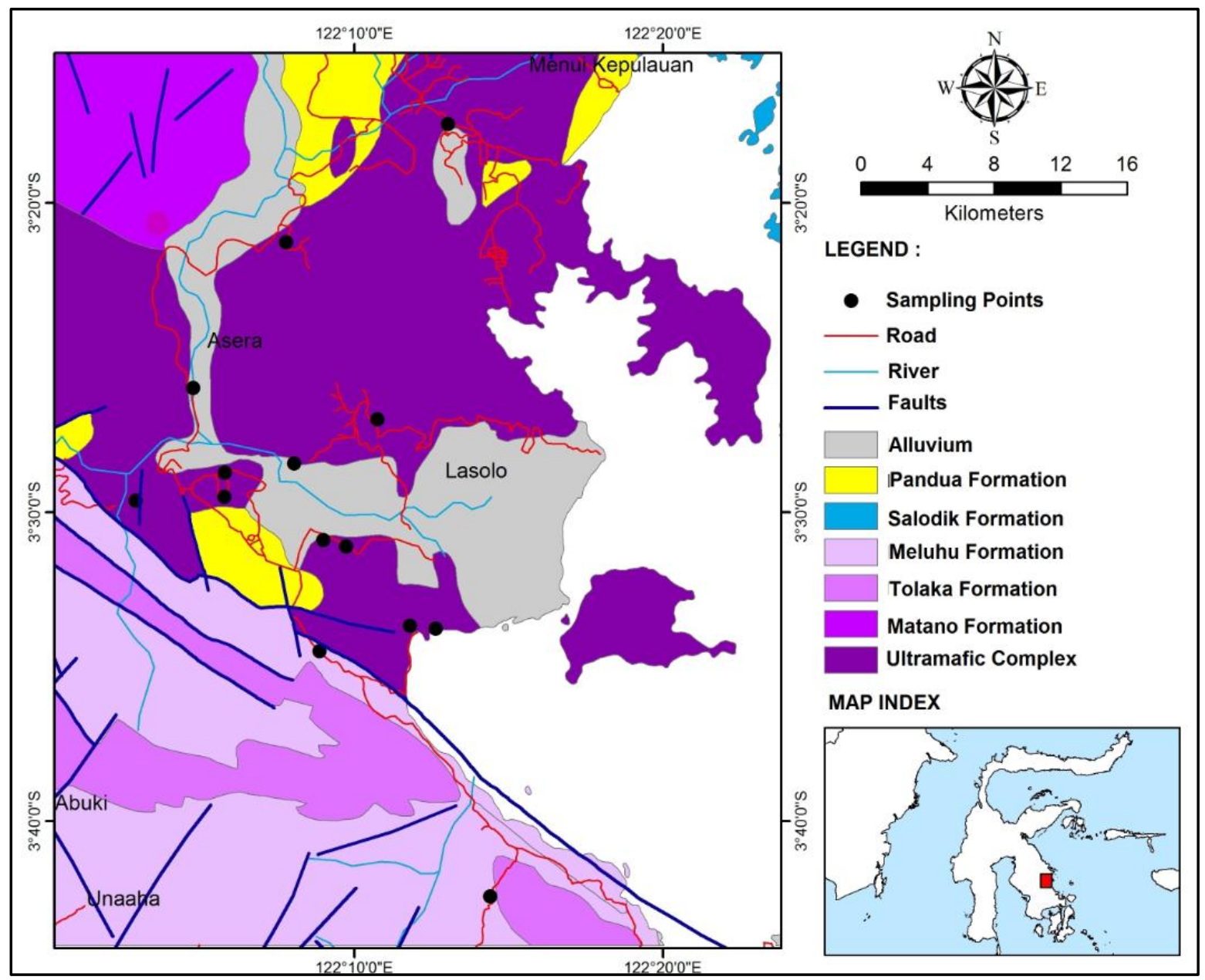

Figure 1.Geological map of research area and sampling locations in North Konawe Regency (modified from [13]).

\section{ANALYTICAL METHOD}

\section{Sample Description}

Nine rock samples collected during fieldwork and passed through chemical analysis. Sampling locations are illustrated in Figure 1. In general, the ultramafic rocks megascopically are greyish to blackish, fine to medium grains, and consist of pyroxene and olivine. Ultramafic rock, typically holocrystalline and porphyritic texture, KUD 02 was taken from abandoned mine area. Talc and magnetite found in this sample. The typical character of relatively fresh ultramafic rocks can be seen in KUD 05 from Tangguluri Village, Asera. Anhedral ultrabasic rocks along with its $2 \mathrm{~m}$ weathered 
layers are located in Wiwirano, near the border of Southeast Sulawesi and Central Sulawesi Provinces KUD 06. Dark collored, holocrystalline, serpentinized, and fractured ultramafic blocks can be found in Laroonoha (KUD 50A). Sample KUD 51 had taken from Lambu Durian Village in Molawe. The sample describes as black-greyish, mediumgrained, holocrystalline, euhedral, partly serpentinized sample. Insitu ultrabasic sample (KUD 54) together with its saprolite, laterite, and soil profiles had studied easily because of recent mining activity in Mandiodo. Garnierite was easy to detect megascopically from this sample as a green nickel within weathered and serpentinized ultramafic rock. Slight fresh to relative weathered dark ultramafic rock had seen in Puuwonuwa (DH 56). Slight fresh black greyish holocrystalline serpentinized ultramafic sample was taken from Amarome (KUD 154). Large ultramafic outcrop in Labungga, Andowia formed a chloritized hill, with veinlets, serpentinized, without garnierite (KUD 156). Some outcrops showed in Figure 2.

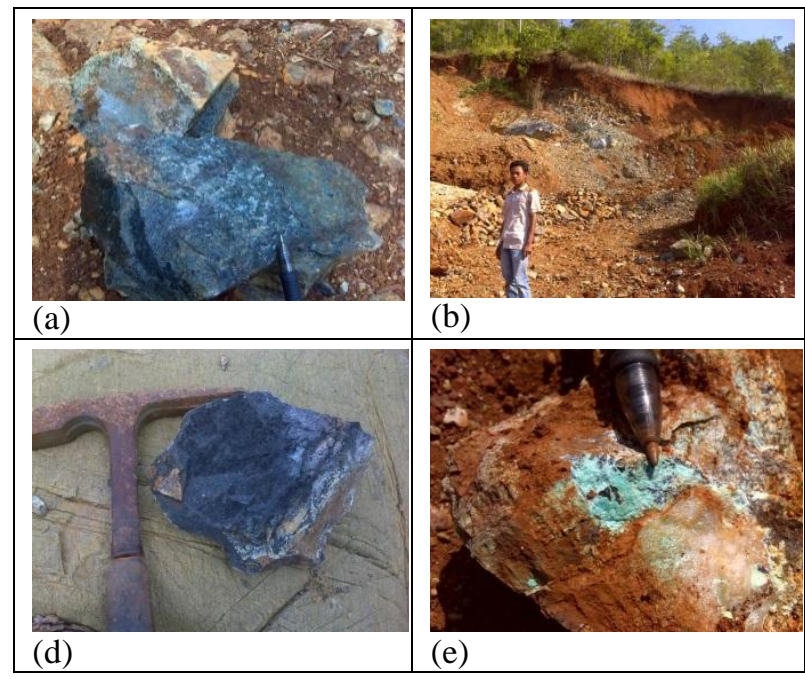

Figure 2. a) Mesh structure of KUD 51; b) Relatively fresh ultramafic and the laterite layer outcrop of KUD 56; c) Massif ultramafic samples of KUD 06; d) Garnierite of KUD 54.

\section{Rock Analysis}

The geochemical character of nine (9) selected ultramafic rock samples in the North Konawe Regency had studied. Chemical composition of the selected samples had measured using X-Ray Fluorescence (XRF) for their major and some trace oxides composition, and Inductively Coupled Plasma-Mass Spectrometry (ICP-MS) for the other trace and rare earth elements. The samples analyzed at Geology Laboratory of Center of Geology Survey, Bandung. After dried for a day in minimum, whole samples were crushed with jaw crusher and separated using a ball mill to obtain particle size of 200 mesh. Pressed pellets were analyzed using the advant XP X-Ray Fluorescence (XRF) method for 12 major oxides $\left(\mathrm{SiO}_{2}, \mathrm{Al}_{2} \mathrm{O}_{3}\right.$, $\mathrm{K}_{2} \mathrm{O}, \mathrm{Fe}_{2} \mathrm{O}_{3}, \mathrm{Na}_{2} \mathrm{O}, \mathrm{CaO}, \mathrm{MgO}, \mathrm{NiO}, \mathrm{Cr}_{2} \mathrm{O}_{3}$, $\mathrm{SO}_{3}, \mathrm{TiO}_{2}$, and $\mathrm{MnO}$ ).

Loss of Ignition (LOI) analysis process started from heat the weighted porcelain crucibles to $300^{\circ} \mathrm{C}$ in a furnace. The crucibles then cooled in a desiccator, thus ensuring that no moisture increased the dry weight measurements. One (1) gram sample then placed in the crucible and heated at $1000^{\circ} \mathrm{C}$ in furnace for about an hour. Sample along with crucible then cooled in desiccator and weighted. The LOI calculated from this formula:

$$
L O I=\frac{A-B}{A-C} \times 100 \%
$$

where: $A=$ mass of crucible + sample

$B=$ mass of crucible + residue

$C=$ mass of empty crucible

REE measurements reported in this study were made via quadrupole iCAP-Q Thermo Fisher Scientific ICP-MS. Samples were dissolved with three acid leaching using nitric 
acid (ultra pure grade), formic acid (ultra pure grade), and perchloric acid (pro analysis grade). Full suites of rare earth elements (La, $\mathrm{Ce}, \mathrm{Pr}, \mathrm{Nd}, \mathrm{Sm}, \mathrm{Eu}, \mathrm{Gd}, \mathrm{Tb}, \mathrm{Dy}, \mathrm{Ho}, \mathrm{Er}, \mathrm{Tm}$, $\mathrm{Yb}$, and $\mathrm{Lu}$ ) as well as six other trace elements (V, Rb, Y, Ba, Th, and $\mathrm{U}$ ) analyzed. The CPS (counts per second) of one blank and six levels of calibration solutions $(0.1,1$, $5,10,25$, and 50) measured to produce the calibration curves of analyzed elements. Computer program of the ICP-MS device transformed elements CPS of samples to concentrations using the previous calibration curves. AGV-2 and GBW 7112 were the two certified reference materials used in this study to certify the quality of measurement results.

\section{RESULT AND DISCUSSION Petrography}

Seven of nine ultramafic samples analyzed under the microscope. The selected samples can be classified into three groups petrographically: lherzolites (KUD 51, KUD 56, and KUD 156), olivine websterite (KUD 154), and olivine-hornblende pyroxenites (KUD 02, KUD 05, KUD 06). As ultramafic rocks, the samples are rich in mafic minerals: olivine, pyroxene, and hornblende. Orthopyroxene and clinopyroxene are relatively in balance ratio in olivine websterite. All samples are holocrystalline and comprised of anhedral crystals bigger than $2.5 \mathrm{~mm}$. These samples are likely to experience tectonic activity with irregular fractures detected in the rock minerals. Several amount of magnetite iron ores tend to be present as alteration mineral. Hornblende is the key difference of the group. The black amphibole only presents in olivinehornblende pyroxenite, not in lherzolite neither in olivine websterite. Some microphotos of the selected samples are presented in Figure 3 whereas petrography data in Table 1.

\section{Major Oxides}

The ultramafic rocks suites characterized by high $\mathrm{Mg}$ values instead of very low silica content (generally less than $45 \%$ ) and low potassium [1]. The most abundant oxides in nine selected ultramafic samples in this study are $\mathrm{MgO}, \mathrm{SiO}_{2}$, and $\mathrm{Fe}_{2} \mathrm{O}_{3}$ (Table 2). The $\mathrm{SiO}_{2}$ and $\mathrm{Fe}_{2} \mathrm{O}_{3 \mathrm{~T}}$ content of ultramafic samples from North Konawe covers a narrow composition $(38.50-41.07 \%)$ and $(8.70-$ $12.29 \%)$ respectively. In contrast, $\mathrm{MgO}$ of the samples is high with broader number $(36.95-44 \%)$. The ultramafic rocks have low amount of other major oxides: $\mathrm{CaO}(0.9$ - $3.55 \%), \mathrm{Al}_{2} \mathrm{O}_{3}\left(0.80\right.$ - 3,16\%), $\mathrm{TiO}_{2}$ $(0.0349-0.148 \%), \mathrm{K}_{2} \mathrm{O}(\leq 0.005 \%)$, and $\mathrm{Na}_{2} \mathrm{O}(\leq 0.0708)$. The LOI proposed as a good indicator of the degree of weathering and organic matter concentration in geology study [15]. The nine ultramafic samples are range from fresh to moderate weathered as LOI value of 0.16 to $11.88 \%$.

Ultramafic complexes often indicate heavy metals potential as nickel, chromium, cobalt and manganese [2, 4]; and even platinum group elements (PGE) [6]. Various studies had conducted related to heavy metal comparison in ultramafic host rocks to the laterization product $[5,16]$. Equal $\mathrm{Ni}$ concentration in the selected samples range from 2,380 to 3,050 ppm, Mn from 959 to $1,260 \mathrm{ppm}, \mathrm{Cr}$ from 2,040 to 2,910 ppm, and $\mathrm{Co}>100 \mathrm{ppm}$. The average values of $\mathrm{Ni}, \mathrm{Mn}$, $\mathrm{Cr}$ and $\mathrm{Co}$ of the nine ultramafic samples are 2,$675 ; 1,074 ; 2,386 ;$ and 117 ppm respectively. This average values of $\mathrm{Ni}$ and $\mathrm{Cr}$ in North Konawe area are higher than the average value for ultramafic rocks of Tuerkian and Wedpohl (Ni 2,000 ppm and $\mathrm{Cr}$ 1,600) [17]. However, Mn average value is 
$<30 \%$ lower than the average proposed value. Moreover, the Ni laterite content is the next interesting topic, as had been studied in South Konawe [12], because some of the sampling points out cropped with weathered ultramafic layers. The ternary diagram of $\mathrm{Cr}$, $\mathrm{Ni}$, and $\mathrm{Mn}$ indicates that $\mathrm{Mn}$ is less than 20 $\%$ of total three heavy metals composition whereas $\mathrm{Cr}$ and $\mathrm{Ni}$ are about the same value (Figure 4).

Classification scheme for volcanic and plutonic rocks based upon their cationic proportions of major elements, expressed as millication had proposed [18]. The diagram is an $\mathrm{X}-\mathrm{Y}$ bivariate graph using the plotting parameters R1 and R2. Almost all of the samples broadly classified as ultramafic rocks, except for KUD 154, which points in gabbro-norite area (Figure 5.a). This is because the $\mathrm{Ca}, \mathrm{Mg}$, and $\mathrm{Al}$ content in KUD 154 are the lowest of all ultramafic samples. Tectonic setting of ophiolitic lavas can be determined using $\mathrm{Ti}$ and $\mathrm{V}$ ration. $\mathrm{Ti} / \mathrm{V}$ of almost of the samples (except KUD 05) are $>20$ and points in the arc tholeiitic environment tectonic setting (Figure 5.b) [19].
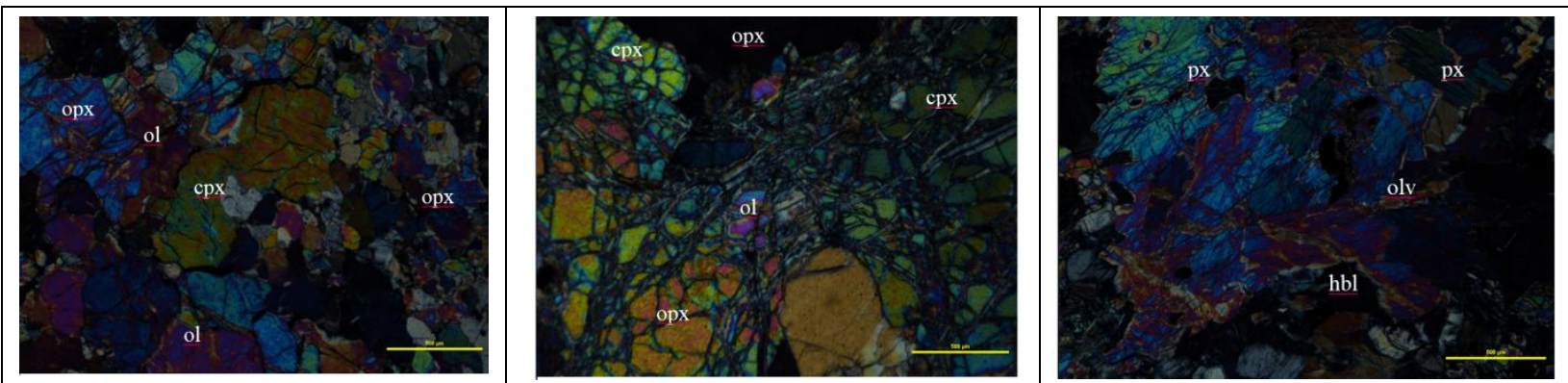

Figure 3. Microphotos of ultamafic samples from North Konawe Regency: a) Lherzolite of KUD 156; b) Olivine websterite of KUD 154; and c) Olivine-hornblende pyroxenite of KUD 05. All pictures are in cross-nicols. Opx = orthopyroxene, $\mathrm{cpx}=$ clinopyroxene, $\mathrm{ol}=$ olivine, $\mathrm{hbl}=$ hornblende.

Table 1. Petrography analysis of selected samples.

\begin{tabular}{|c|c|c|c|c|c|c|c|}
\hline Sample code & KUD 02 & KUD 05 & KUD 06 & KUD 51 & KUD 56 & KUD 156 & KUD 154 \\
\hline Sample name & $\begin{array}{l}\text { Olivine- } \\
\text { hornblend } \\
\text { pyroxenite }\end{array}$ & $\begin{array}{l}\text { Olivine- } \\
\text { hornblend } \\
\text { pyroxenite }\end{array}$ & $\begin{array}{l}\text { Olivine- } \\
\text { hornblend } \\
\text { pyroxenite }\end{array}$ & Lherzolite & Lherzolite & Lherzolite & $\begin{array}{c}\text { Olivine } \\
\text { Websterite }\end{array}$ \\
\hline \multicolumn{8}{|l|}{ Phenocryst } \\
\hline Orthopyroxene & & & & 17 & 17 & 23 & 32 \\
\hline Clinopyroxene & & & & 24 & 26 & 28 & 31 \\
\hline Olivine & 22 & 16 & 17 & 48 & 32 & 39 & 24 \\
\hline Pyroxene & 38 & 42 & 39 & & & & \\
\hline Hornblende & 28 & 32 & 33 & & & & \\
\hline Groundmass & - & - & - & - & - & - & - \\
\hline Accessory minerals & - & - & - & - & - & - & - \\
\hline \multicolumn{8}{|l|}{ Alteration minerals } \\
\hline Oxidated/mineral ore & 7 & 5 & 6 & 6 & 5 & 5 & 5 \\
\hline Chlorite-chloritoid & - & - & - & - & - & - & - \\
\hline Clayish mineral & 5 & 5 & 5 & 5 & 20 & 5 & 8 \\
\hline Calsite & - & - & - & - & - & - & - \\
\hline Epidote & - & - & - & - & - & - & - \\
\hline
\end{tabular}


Table 2. Geochemical content of selected samples from North Konawe

\begin{tabular}{|c|c|c|c|c|c|c|c|c|c|}
\hline & $\begin{array}{c}\text { KUD } \\
02\end{array}$ & $\begin{array}{c}\text { KUD } \\
05\end{array}$ & $\begin{array}{c}\text { KUD } \\
06\end{array}$ & $\begin{array}{c}\text { KUD } \\
50 A\end{array}$ & $\begin{array}{c}\text { KUD } \\
51\end{array}$ & $\begin{array}{c}\text { KUD } \\
54\end{array}$ & $\begin{array}{c}\text { KUD } \\
56\end{array}$ & $\begin{array}{c}\text { KUD } \\
154\end{array}$ & $\begin{array}{c}\text { KUD } \\
156\end{array}$ \\
\hline $\mathrm{SiO}_{2}(\%)$ & 38.96 & 38.48 & 38.58 & 38.50 & 40.05 & 39.08 & 39.25 & 39.41 & 41.07 \\
\hline $\mathbf{A l}_{2} \mathbf{O}_{3}$ & 0.80 & 3.16 & 1.15 & 1.69 & 2.55 & 1.02 & 0.83 & 0.98 & 2.92 \\
\hline $\mathbf{K}_{2} \mathbf{O}$ & n.d. & 0.0027 & 0.0050 & 0.0029 & n.d. & 0.0040 & 0.0028 & n.d. & 0.0106 \\
\hline $\mathrm{Fe}_{2} \mathrm{O}_{3}$ & 9.70 & 8.55 & 10.50 & 8.53 & 9.45 & 9.92 & 9.27 & 8.70 & 12.29 \\
\hline $\mathrm{Na}_{2} \mathrm{O}$ & n.d. & n.d. & n.d. & n.d. & 0.0708 & n.d. & n.d. & n.d. & 0.1500 \\
\hline $\mathrm{CaO}$ & 0.96 & 3.14 & 1.72 & 1.26 & 2.10 & 1.14 & 0.90 & 0.75 & 3.55 \\
\hline MgO & 43.54 & 36.95 & 43.44 & 42.07 & 41.65 & 41.31 & 44.00 & 37.39 & 39.31 \\
\hline $\mathrm{TiO}_{2}$ & 0.0086 & 0.1480 & 0.0345 & 0.0349 & 0.0714 & 0.0134 & 0.0108 & 0.0117 & 0.1120 \\
\hline $\mathrm{SO}_{3}$ & 0.0415 & 0.0570 & 0.0285 & 0.0293 & 0.0387 & 0.0256 & 0.0243 & 0.0173 & n.d. \\
\hline $\mathrm{NiO}$ & 0.3520 & 0.3060 & 0.3820 & 0.3030 & 0.3080 & 0.3640 & 0.3880 & 0.3320 & 0.3290 \\
\hline Ni (ppm) & 2770 & 2400 & 3000 & 2380 & 2420 & 2860 & 3050 & 2610 & 2590 \\
\hline $\mathrm{Cr}_{2} \mathrm{O}_{3}$ & 0.3500 & 0.3040 & 0.3630 & 0.3400 & 0.3600 & 0.3620 & 0.2980 & 0.3350 & 0.4250 \\
\hline $\mathrm{Cr}(\mathrm{ppm})$ & 2400 & 2080 & 2480 & 2330 & 2470 & 2480 & 2910 & 2290 & 2060 \\
\hline MnO & 0.1400 & 0.1290 & 0.1470 & 0.1240 & 0.1410 & 0.1430 & 0.1290 & 0.1320 & 0.1630 \\
\hline Mn (ppm) & 1090 & 998 & 1140 & 959 & 1090 & 1110 & 999 & 1020 & 1260 \\
\hline $\mathrm{Co}_{3} \mathrm{O}_{4}$ & 0.0151 & 0.0155 & 0.0179 & 0.0153 & 0.0164 & 0.0173 & 0.0152 & 0.0149 & 0.0165 \\
\hline Co (ppm) & 111 & 114 & 131 & 112 & 120 & 127 & 112 & 109 & 121 \\
\hline LOI & 5.08 & 8.66 & 3.59 & 7.05 & 3.16 & 6.56 & 4.85 & 11.88 & 0.16 \\
\hline $\mathrm{CaO} / \mathrm{Al}_{2} \mathrm{O}_{3}$ & 1.20 & 0.99 & 1.50 & 0.75 & 0.82 & 1.12 & 1.09 & 0.76 & 1.22 \\
\hline $\mathbf{V}(\mathbf{p p m})$ & 57.95 & 29.61 & 47.46 & 50.93 & 118.57 & 83.04 & 51.54 & 78.82 & 94.66 \\
\hline $\mathbf{R b}$ & 69.85 & 69.57 & 69.72 & 71.99 & 73.32 & 72.08 & 71.07 & 73.05 & 71.82 \\
\hline $\mathbf{Y}$ & 0.40 & 1.86 & 0.62 & 1.01 & 2.31 & 0.44 & 0.62 & 0.27 & 2.53 \\
\hline $\mathbf{B a}$ & 15.30 & 11.06 & 18.85 & 19.84 & 18.87 & 18.49 & 21.07 & 28.46 & 24.66 \\
\hline Th & 0.41 & 0.25 & 0.01 & 0.10 & 0.07 & 0.38 & 0.14 & 0.50 & 0.29 \\
\hline $\mathbf{U}$ & 0.34 & 0.38 & 0.31 & 0.33 & 0.33 & 0.35 & 0.36 & 0.36 & 0.35 \\
\hline La & 0.4111 & 0.9750 & 0.3541 & 0.6669 & 0.6354 & 0.2455 & 0.3024 & 0.3235 & 0.2799 \\
\hline $\mathrm{Ce}$ & 1.1680 & 2.3484 & 0.8729 & 0.8485 & 0.9002 & 0.6250 & 0.7165 & 0.7186 & 0.8193 \\
\hline $\operatorname{Pr}$ & 0.0741 & 0.5320 & 0.0745 & 0.0870 & 0.0916 & 0.3586 & 0.0575 & 0.0732 & 0.1059 \\
\hline Nd & 0.2399 & 1.0161 & 0.2550 & 0.2966 & 0.4183 & 0.1614 & 0.1924 & 0.2179 & 0.4846 \\
\hline Sm & 0.0476 & 0.2621 & 0.0728 & 0.0848 & 0.1663 & 0.0340 & 0.0365 & 0.0487 & 0.2003 \\
\hline Eu & n.d. & 0.0510 & 0.0078 & 0.0165 & 0.0485 & n.d. & n.d. & 0.0070 & 0.0709 \\
\hline Gd & 0.0522 & 0.3052 & 0.0987 & 0.1213 & 0.2518 & 0.0558 & 0.0662 & 0.0627 & 0.2933 \\
\hline Tb & 0.0083 & 0.0562 & 0.0184 & 0.0265 & 0.0538 & 0.0102 & 0.0106 & 0.0192 & 0.0718 \\
\hline Dy & 0.0616 & 0.3223 & 0.1162 & 0.1617 & 0.3591 & 0.0739 & 0.0619 & 0.0667 & 0.4094 \\
\hline Ho & 0.0178 & 0.0759 & 0.0287 & 0.0405 & 0.0897 & 0.0192 & 0.0185 & 0.0249 & 0.1087 \\
\hline $\mathbf{E r}$ & 0.0714 & 0.2126 & 0.0862 & 0.1178 & 0.2627 & 0.0682 & 0.0582 & 0.0573 & 0.2982 \\
\hline Tm & 0.0134 & 0.0339 & 0.0143 & 0.0228 & 0.0419 & 0.0135 & 0.0161 & 0.0217 & 0.0554 \\
\hline $\mathbf{Y b}$ & 0.1049 & 0.1920 & 0.0869 & 0.1288 & 0.2615 & 0.0826 & 0.0711 & 0.0706 & 0.2795 \\
\hline Lu & 0.0216 & 0.0330 & 0.0162 & 0.0229 & 0.0436 & 0.0155 & 0.0135 & 0.0240 & 0.0570 \\
\hline
\end{tabular}




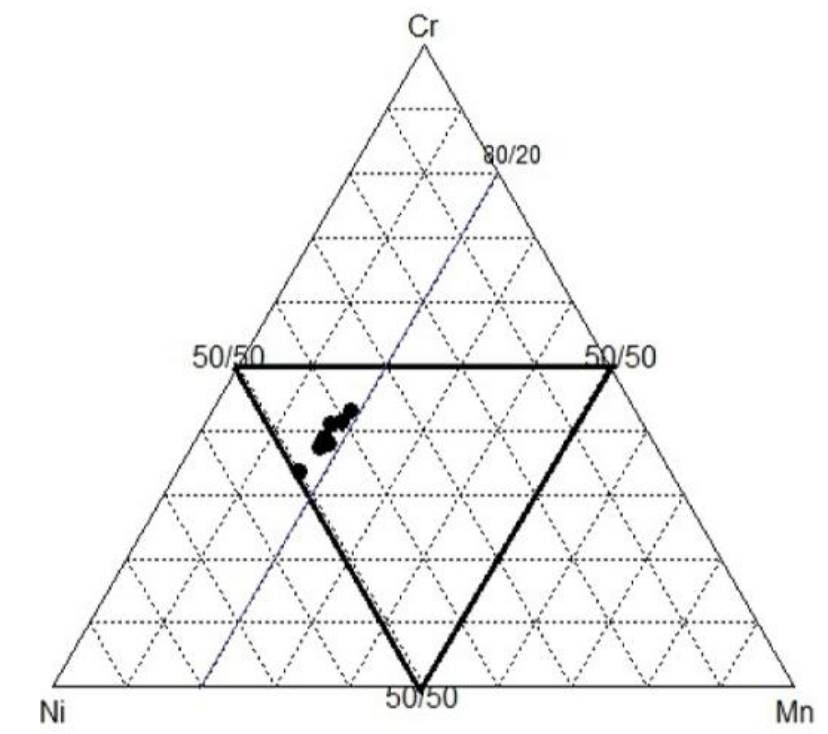

Figure 4. Ternary plot of $\mathrm{Cr}, \mathrm{Ni}$, and $\mathrm{Mn}$ of ultramafic rocks from South Konawe.

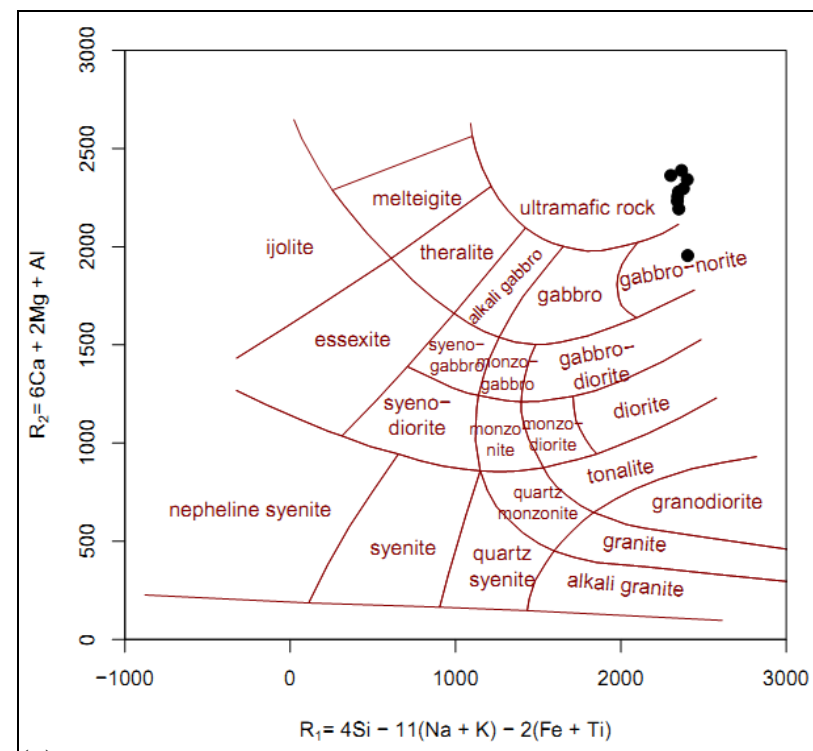

(a)

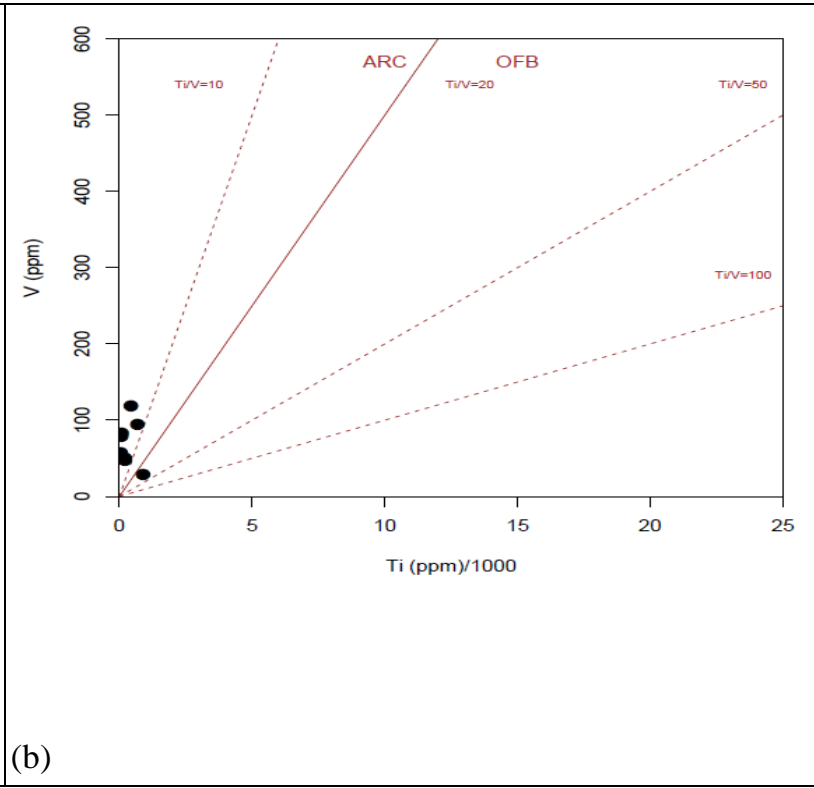

Figure 5.a) Classification of selected samples using R1-R2 diagram [18]. Most of the samples plotted in ultramafic rock field, except KUD 154 in gabbro-norite; b) Ti/1000 vs V tectonic discrimination diagram of studied samples [19]. ARC: arc basalt; OFB: ocean floor basalt (MORB).

\section{Trace and Rare Earth Elements}

The studied ultramafic samples contain wide range of totally six trace elements: V, $\mathrm{Rb}, \mathrm{Y}, \mathrm{Ba}$, Th and $\mathrm{U}$ of 119 to $213 \mathrm{ppm}$ (mean value of $161 \mathrm{ppm}$ ). Vanadium and Rubidium are the two most abundant trace elements of the samples, exceed $65 \mathrm{ppm}$ and $70 \mathrm{ppm}$ respectively. Trace and REE content plotted in spider diagrams to constrain more about tectonic settings and genesis of rocks. In order to prevent Oddo-Harkins effect in drawing the spider diagrams, elemental values of samples in this study normalized to primitive mantle value [20]. Large-ion lithophile elements (LILE) generally enriched whereas high field strength elements (HFSE) depleted in ultramafic samples from North Konawe compared to primitive mantle value 
(Figure 6a). Positive $\mathrm{Pr}$ and negative $\mathrm{Eu}$ anomalies depicted in both extended REE and REE spider diagrams (Figure 6.a and b). Both diagrams confirm a more likely pattern of studied samples to OIB rather than MORB and confirm the previous of tectonic environment in Figure 5.b.

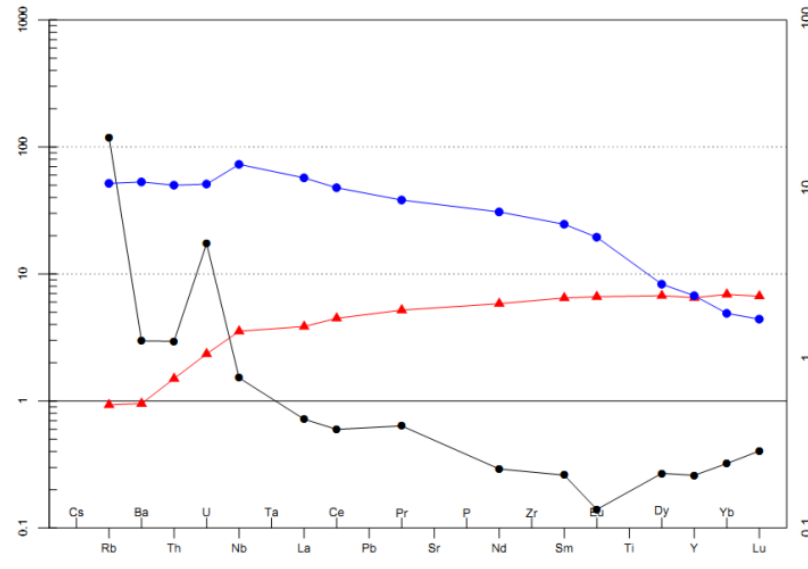

(a)

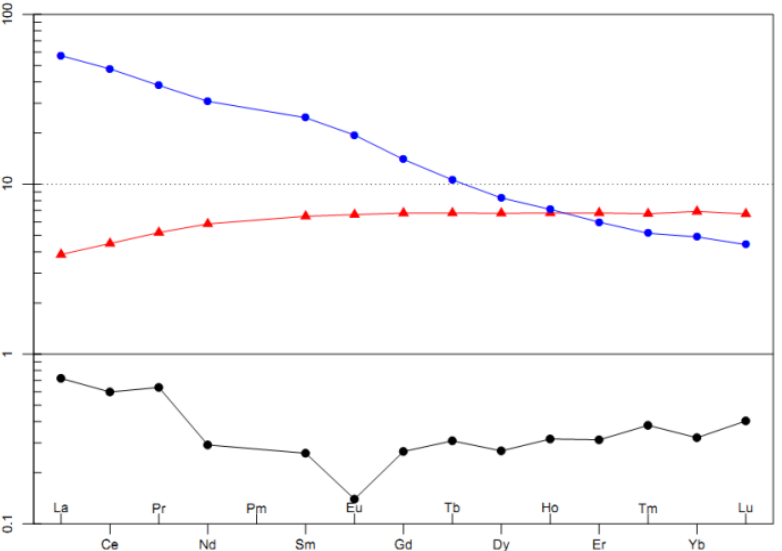

(b)

Figure 6.Comparison of this study to MORB and OIB [21]. All numbers are normalized to Primitive mantle [20]: a) trace elements; and b) rare earth elements. Black = mean ultramafic value of this study, blue $=$ OIB, red = MORB.

Two subgroups of the Ultramafic Complex

Based on petrography analysis, KUD 02, KUD 05, and KUD 06 are classified as olivine-hornblende pyroxenites whereas KUD 51, KUD 56, and KUD 156 as lherzolites. KUD 154 is the only sample, which proposed as olivine websterite while KUD 50A and KUD 54 were not analyzed under microscope, and then the two last samples cannot be classified into any subgroups. The whole-rock chemical data can provide useful information on the course of fractional crystalization/magmatic evolution and applicated here to contrast olivine-hornblende pyroxenite and lherzolite. Binary plots against $\mathrm{MgO}$ reveal how much of the original chemistry of the ultramafic rocks is affected $[22,23]$. This is because $\mathrm{MgO}$ is an important component of the solid phases in equilibrium with mafic melts and shows a great deal of variation, either because of the breakdown of magnesian phases during partial melting, or because of their removal during fractional crystallization [24]. Eventhough these two subgroups show negative correlation of $\mathrm{Al}_{2} \mathrm{O}_{3}, \mathrm{CaO}$, and $\mathrm{TiO}_{2}$ with positive correlation of $\mathrm{Ni}$, and $\mathrm{REE}$ against $\mathrm{MgO}$, they denoted different slopes. Obvious distinctions indication in bivariate plots of $\mathrm{SiO}_{2}, \mathrm{Fe}_{2} \mathrm{O}_{3 \mathrm{~T}}$, $\mathrm{Cr}$, and $\mathrm{Mn}$ versus magnesium oxide: olivinhornblende pyroxenites tend to rise with the increasing $\mathrm{MgO}$ whilst lherzolites display conversely (Figure 7).

Ratio of $\mathrm{CaO} / \mathrm{Al}_{2} \mathrm{O}_{3}$ increases during plagioclase removal whereas it remains constant during olivine fractionation [23]. The mean $\mathrm{CaO} / \mathrm{Al}_{2} \mathrm{O}_{3}$ ratio of the nine selected ultramafic samples is 1.05 that is greater than 0.8 and may be due the plagioclase fractionation. Fractional crystallization during magma evolution may be associated with crustal contamination [25] and can modify the elemental composition. Crustal materials are rich in $\mathrm{K}_{2} \mathrm{O}, \mathrm{Na}_{2} \mathrm{O}$ and LILEs but depleted in $\mathrm{P}_{2} \mathrm{O}_{5}$ and $\mathrm{TiO}_{2}$. Very low $\mathrm{K}_{2} \mathrm{O}$ and $\mathrm{Na}_{2} \mathrm{O}$ concentrations in studied 
samples (some of them are below detection limit) suggest that the ultramafic complex in North Konawe favoured minimal crustal contamination. As lithophile elements, REEs had enriched in the earth's crust. This group invariably occurs together naturally because all are trivalent (except for $\mathrm{Ce}^{+4}$ and $\mathrm{Eu}^{+2}$ in some environments) and have similar ionic radii [26]. This minimal crustal contamination based on $\mathrm{CaO} / \mathrm{Al}_{2} \mathrm{O}_{3}$ ratio explains the low REE content of the samples ( $<7 \mathrm{ppm})$. Moreover, the ratio is relatively higher in olivine-hornblende pyroxenites (1.23) than lhezorlites (1.04) and reveals that plagioclase was might fractionated more in the first group.

Most of REE of the nine ultramafic samples are below the primitive mantle values and could become another clue of minimal crust contamination to the complex (Figure 8a). Negative Eu anomaly in these samples depicts plagioclase fractionation. Eu anomaly $\left(\mathrm{Eu} / \mathrm{Eu}^{*}\right)$ was calculated based on formula from previous studies: $\mathrm{Eu} / \mathrm{Eu}^{*}=$ $\mathrm{Eu}_{\mathrm{N}} /\left(\mathrm{Sm}_{\mathrm{N}} \times \mathrm{Gd}_{\mathrm{N}}\right)^{1 / 2}[27$-29]. Average $\mathrm{Eu}$ negative anomalies for olivine hornblend pyroxenites and lherzolites are 0.30 and 0.56 , respectively; indicate olivine hornblende pyroxenites experienced more fractionation of plagioclase. Depletion of LREE was steeper in hornblende group whereas lhezorlites show weak enrichment in HREE pattern (Figure 8). Olivine hornblende pyroxenites were slight more REE fractionated than lherzolites by $(\mathrm{La} / \mathrm{Lu})_{\mathrm{N}}$ of 2.43 and 1.44 , respectively. 

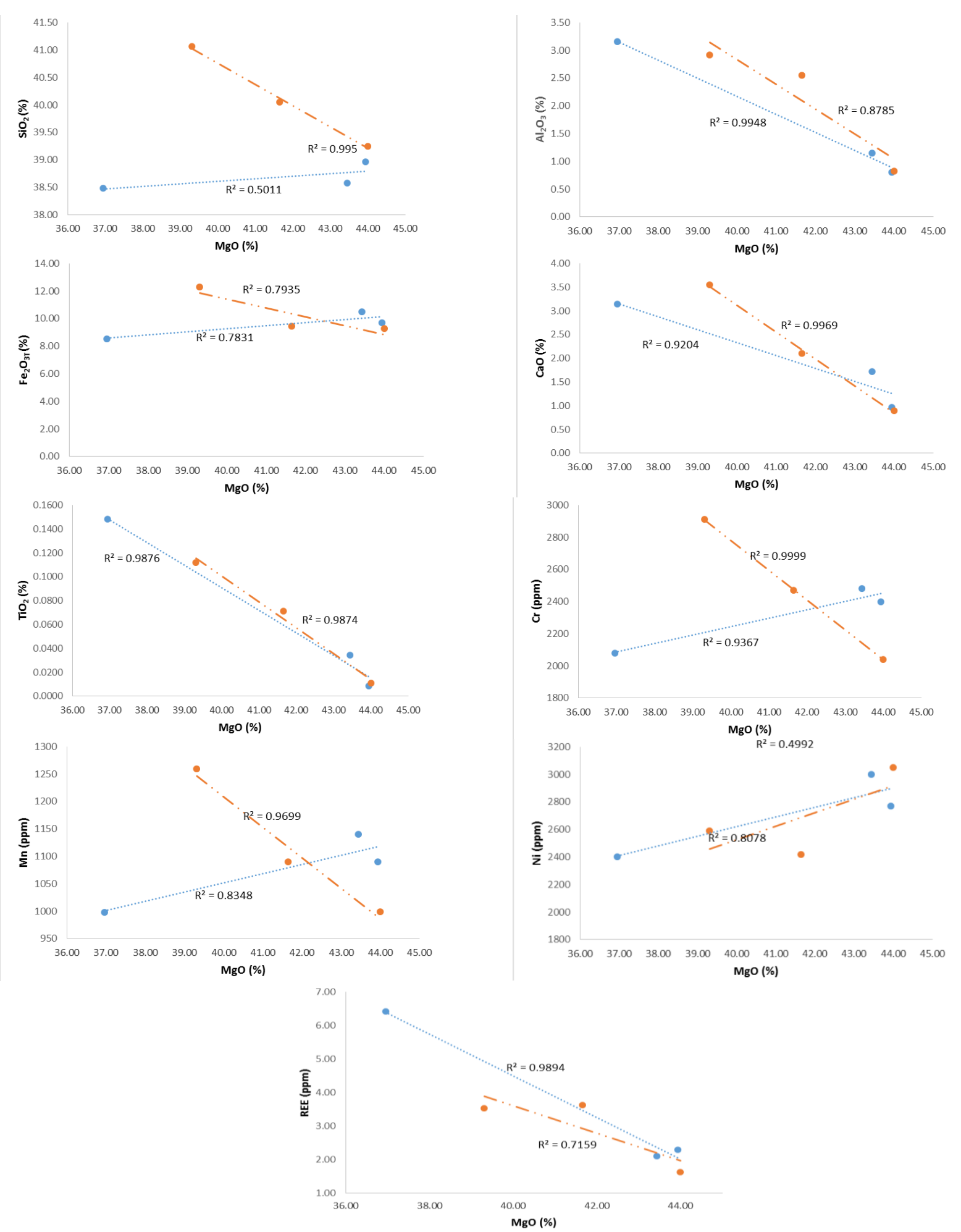

Figure 7. Bivariate plots against $\mathrm{MgO}$ to reveal the two subgroups of ultramafic complex. Blue is lhezorlites and orange is olivin-hornblende pyroxenites. 


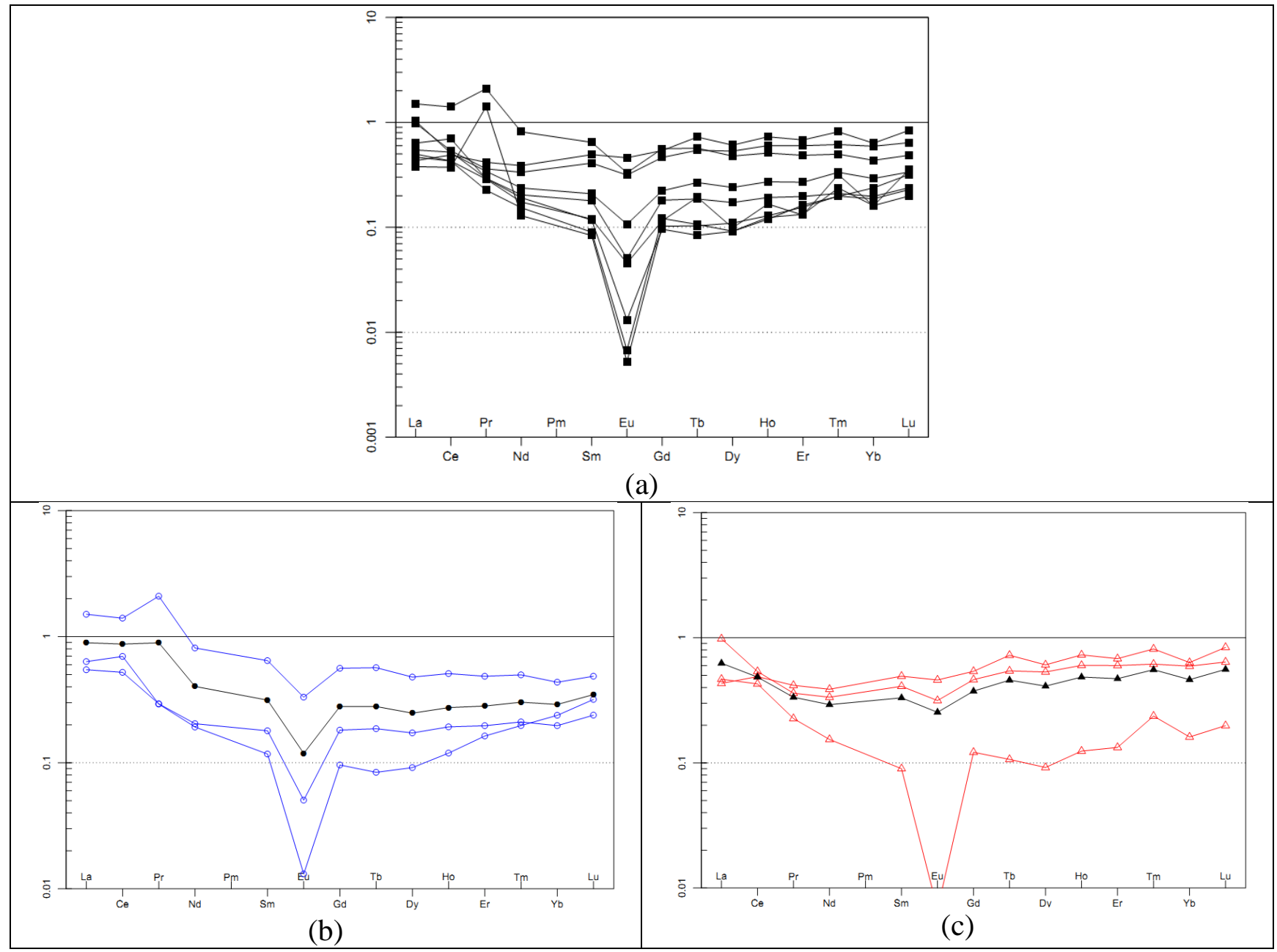

Figure 8. a) Spider REE plot of all nine ultramafic rocks of this study; b) Spider REE of olivine hornblende pyroxenites (black is the mean value); c) Spider REE of lherzolites (black is the mean value).

\section{CONCLUSIONS}

Ophiolite complex in North Konawe Regency largely occupied by ultramafic rocks and it confirmed in petrography and geochemistry analysis. The selected samples are rich in mafic minerals whereas $\mathrm{SiO}_{2}$ is far under $45 \%$ (38.50 - $41.07 \%)$. $\mathrm{MgO}$ and $\mathrm{Fe}_{2} \mathrm{O}_{3 \mathrm{~T}}$ are abundant whilst $\mathrm{Na}_{2} \mathrm{O}, \mathrm{K}_{2} \mathrm{O}$, and $\mathrm{TiO}_{2}$ are below $1 \%$. The $\mathrm{Ni}$ and $\mathrm{Cr}$ elements are relatively high, both are exceed 2,300 ppm. Arc tholeiitic environment tectonic setting of the ophiolite are confirmed by vanadium versus titanium ratio and spider REE diagram. The selected samples are enriched in high field strength elements whilst rare earth elements value are low. The samples were experienced plagioclase fractionation based on $\mathrm{CaO}$ to $\mathrm{Al}_{2} \mathrm{O}_{3}$ ratio with $\mathrm{Eu}$ negative anomaly. Geochemical contents depict more about the differencies of lherzolites and olivine hornblende pyroxenites. Relatively fresh ultramafic and the laterite layer are outcropped in locations in North Konawe Regency and geochemical character comparison would become interesting object.

\section{Acknowledgement}

This study financially supported by Center for Geology Survey. Writers would like to thank the Head of Center for Geology Survey for the publicity permission. Thank 
you to Dr. Purnama Sendjaja, Dian Hari Saputro and Iwan Rudiawan for their help in fieldwork and discussion about ophiolite. The laboratory data would not be obtained well without the assistances from Bayu Himawan, Irfanny Agustiani, Indah and Citra. Thanks to Dwi Putri Novitasari for the discussion about computer programs.

\section{REFERENCES}

[1] K. Attoh, M. J. Evans, and M. E. Bickford, "Geochemistry of an Ultramafic-Rodingite Rock Association in The Paleoproterozoic Dixcove Greenstone Belt, Southwestern Ghana,"J. African Earth Sci., vol. 45, pp. 333-346, 2006.

[2] M. M. Hariri, "Petrogaphical and Geochemical Characteristics of The Ultramafic Roks of Jabal Zalm, Central Arabian Shield, Saudi Arabia," Arab. J. Sci. Eng., vol. 29, no. 2A, pp. 23-133, 2004.

[3] G. J. Heggie, S. J. Barnes, and M. L. Fiorentini, "Application of lithogeochemistry in The Assessment of Nickel-Sulphide Potential in Komatiite Belts from Northern Finland and Norway," Bull. Geol. Soc. Finl., vol. 85, pp. 107126, 2013.

[4] A. Kumar and S. K. Maiti, "Availability of Chromium, Nickel and Other Associated Heavy Metals of Ultramafic and Serpentine Soil/Rock and in Plants," Int. J. Emerg. Technol. Adv. Eng., vol. 3, no. 2, pp. 256-268, 2013.

[5] C. V. Sagapoa, A. Imai, and K. Watanabe, "Laterization Process of Ultramafic Rocks in Siruka, Solomon Island," J. Nov. Carbon Resour. Sci., vol. 3, pp. 32-39, 2011.

[6] P. C. Lightfoot, "Advances in Ni-Cu-PGE Sulphide Deposit Models and Implications for Exploration Technologies," in Proceedings of Exploration 07: Fifth Decennial International Conference on Mineral Exploration, 2007, pp. 629-646.

[7] V. Balaram, S. P. Singh, M. Satyanarayanan, and K. V. Anjaiah, "Platinum Group Elements Geochemistry of Ultramafic and Associated Rocks from Pindar in Madawara Igneous Complex, Bundelkhand Massif, Central India," J. Earth Syst. Sci., vol. 122, no. 1, pp. 79-91, 2013.

[8] F. Zaccarini, A. Idrus, and G. Garuti, "Chromite Composition and Accessory Minerals in
Chromitites from Sulawesi, Indonesia: Their Genetic Significance," Minerals, vol. 46, no. 6, 2016.

[9] Moe'tamar, "Inventarisasi Nikel di Kabupaten Konawe, Provinsi Sulawesi Tenggara," dalamProceeding Pemaparan Hasil Kegiatan Lapangan dan Non Lapangan Tahun 2007 Pusat Sumber Daya Geologi, 2007.

[10] I. Nurhasanah, V. Isnaniawardhani, dan N. Sulaksana, "Penentuan Kawasan Pertambangan Berbasis Sektor Komoditas Unggulan Sumberdaya Nikel Kabupaten Konawe dan Konawe Utara Provinsi Sulawesi Tenggara," Bul. Sumber Daya Geol., vol. 8, no. 2, pp. 41-53, 2013.

[11] T. R. Charlton, "Tertiary evolution of the Eastern Indonesia Collision Complex," J. Asian Earth Sci., vol. 18, pp. 603-631, 2000.

[12] Syafrizal, K. Anggayana, dan D. Guntoro, "Karakterisasi Mineralogi Endapan Nikel Laterit di Daerah Tinanggea Kabapaten Konawe Selatan. Sulawesi Selatan," J. Teknol. Miner., vol. 18, no. 4, pp. 211-220, 2011.

[13] E. Rusmana, D. Sukarna, E. Haryono, dan T. O. Simandjuntak, Peta Geologi Lembar LasusuaKendari, Sulawesi, skala 1:250.000. Pusat Penelitian dan Pengembangan Geologi, 1993.

[14] S. Rab, Geologic Map of Indonesia, Sheet VIII, Ujungpandang, sekala 1:1.000.000. Geological Survey of Indonesia, 1975.

[15] H. Ishiga, K. Dozen, and C. Yamazaki, "Geochemical Implications of The Weathering Process of Granitoids and Formation of Black Soils-an Example From The San'in District, Southwest Japan," Geosci. Rep. Shimane Univ., vol. 32, pp. 1-11, 2013.

[16] G. Ratie, D. Jouvin, J. Garnier, R. Oliver, S. Miska, E. Guimaraes, L. C. Veira, Y. Sivry, I. Zelano, M. Pelletier, F. Thil, and C. Quantin, "Nickel Isotope Fractionation During Tropical Weathering of Ultramafic Rocks," Chem. Geol., vol. 402, pp. 68-76, 2015.

[17] K. K. Turekian and Wedepohl, "Distribution of the Elements in Some Major Units of Earth's Crust," Chem. Geol., vol. 72, pp. 175-192, 1961.

[18] H. De La Roche, J. Lettier, P. G. Claude, and M. Marchal, "A Classification of Volcanic and Plutonic Rocks Using R1-R2 Diagrams and Major Elements Analyses-Its Relationship and Current Nomenclature," Chem. Geol., vol. 72, pp. 175-192, 1980. 
[19] J. W. Shervais, "Ti-V Plots and The Petrogenesis of Modern and Ophiolitic Lavas, Earth Planet," Sci. Lett. J., vol. 59, pp. 101-118, 1982.

[20] W. F. Mcdonough and S. Sun, "Composition of The Earth," Chem. Geol., vol. 120, pp. 223-253, 1995.

[21] W. F. Mcdonough and S. Sun, "Chemical and Isotopic Systematics of Oceanic Basalts: Implications for Mantle Composition and Processes," Geol. Soc. Spec. Publ., vol. 42, pp. 313-345, 1989.

[22] B. Yibas, W. U. Reimold, C. R. Anhaeusser, and C. Koeberl, "Geochemistry of The Mafic Rocks of The Ophiolitic Fold and Thrust Belts of Southern Ethiopia: Constraints on The Tectonic Regime during The Neoproterozoic (900-700 MA)," Precambrian Res., vol. 121, no. 3-4, pp. 157-183, 2003

[23] A. M. Dar, A. R. Mir, K. Anbarasu, M. Satyanarayanan, V. Balaram, D. V. S. Rao, and S. N. Charan, "Mafic and Ultramafic Rocks in Parts of the Bhavani Complex, Tamil Nadu, Southern India: Geochemistry constraints," J. Geol. Min. Res., vol. 6, no. 2, pp. 18-27, 2014.

[24] H. R. Rollinson, Using Geochemical Data: Evaluation, Presentation, Interpretation. London: England: Longman Scientific \& Technical, 1993.
[25] D. J. DePaolo, "Trace Element and Isotopic Effects of Combined Wallrock Assimilation and Fractional Crystallization," Earth Planet. Sci. Lett., vol. 53, pp. 189-202, 1981.

[26] S. B. Castor and J. B. Hendrick, Rare Earth Elements, in Kogel, 7th ed. Society for Mining Metallurgy, and Exploration Inc., 2006.

[27] J. Y. Yang, M. C. Qian, S. Z. Bing, Z. X. Guo, and Z. H. Sheng, "The Early Paleozoic Tiefosi Syn-Collisional Granite in The Northern Dabie Orogen: Geochronological and Geochemical Constraints," Sci. China Ser. D Earth Sci., vol. 50, no. 6, pp. 847-856, 2007.

[28] K. Sanematsu, T. Moriyama, L. Sotouky, and Y. Watanabe, "Laterization of Basalts and Sandstone Associated with The Enrichment of Al, Ga and Sc in The Bolaven Plateau, Southern Laos," Bull. Geol. Surv. Japan, vol. 62, pp. 105-129, 2011.

[29] P. Kaur, N. Chaudi, A. W. Hormann, I. Razcek, M. Okrusch, S. Skora, and L. P. Baumgartner, "Two-Stage, Extreme Albitization of A-type Granites from Rajasthan, NW India," J. Petrol. pp. 1-30, 2012. 